\title{
Practices in primary health care oriented toward the harmful consumption of drugs*
}

\author{
PRÁTICAS NAATENÇÃO BÁSICA VOLTADAS PARA O CONSUMO PREJUDICIAL DE DROGAS \\ LAS PRÁCTICAS EN LAATENCIÓN PRIMARIA DE SALUD RELACIONADOS CON EL \\ CONSUMO NOCIVO DE LAS DROGAS
}

\author{
Heloisa da Veiga Coelho¹, Cássia Baldini Soares²
}

\begin{abstract}
Objective: To analyze the practices of primary care focused on the harmful consumption of drugs. Method: This is a qualitative study, developed with a dialectical-critical approach. Data collection was carried out through semi-structured interviews with 10 employees of a basic health unit (UBS). Results: The demands are not accepted, and if they go beyond the barriers shaped by the historical absence of health care practices for drug users and moralistic and preconceived ideologies, they are not reinterpreted as health needs; practices that meet these demands and go beyond the barriers are poor; the functionalist approach, which explains drug use as a disease and considers drug users as deviants, supports the few existing practices. Conclusion: primary health care is mistakenly focused on addiction; it lacks structural elements of the production process in health and internal dynamics of the working processes that would foster the development of collective practices.
\end{abstract}

\section{RESUMO}

Objetivo: Analisar as práticas de atenção básica voltadas ao consumo prejudicial de drogas. Método: Estudo qualitativo, desenvolvido na perspectiva dialético-crítica. A coleta de dados foi realizada através de entrevistas semiestruturadas com 10 trabalhadores de uma Unidade Básica de Saúde (UBS). Resultados: As demandas não são acolhidas e, quando ultrapassam as barreiras - conformadas pela ausência histórica de práticas de atenção à saúde ao usuário de drogas e por ideologias moralistas e preconceituosas -, não são reinterpretadas como necessidades de saúde; as práticas que atendem essas demandas são precárias; a perspectiva funcionalista, que compreende o consumo de drogas como doença e considera usuários de drogas como desviantes, embasa as escassas práticas existentes. Conclusão: $A$ atenção básica encontra-se equivocamente voltada para a dependência; carece de elementos estruturais do processo de produção em saúde e da dinamicidade interna aos processos de trabalho, que favoreceriam o desenvolvimento de práticas coletivas.

\section{DESCRITORES}

Usuários de drogas

Atenção Primária à Saúde

Estratégia Saúde da Família

Pessoal de saúde

\section{RESUMEN}

Objetivo: El estudio tiene como objetivo analizar las prácticas de atención primaria dirigidos a lo consumo prejudicial de drogas. Método: Se trata de un estudio cualitativo, desarrollado en la perspectiva dialéctica crítica. La recolección de datos se realizó a través de entrevistas semiestructuradas con 10 empleados de una Unidad Básica de Salud. Resultados: Muestran que: las demandas no son aceptadas, y si van más allá de las barreras - formadas por la ausencia histórica de la práctica de la atención de salud para los consumidores de drogas y las ideologías morales y preconcebidas -, no son reinterpretados como necesidades de salud; las prácticas que satisfagan esas demandas son pobres; detrás de estas escasas prácticas, está la perspectiva funcionalista, que considera el uso de drogas como una enfermedad y los usuarios de drogas como desviados; los trabajadores valoran la formación clínica y culpan a los usuarios por los problemas que enfrentan. Conclusión: Se pode concluir que la atención primaria: es equívoca hacia el objeto de la dependencia; carece de los elementos estructurales del proceso de producción en la salud y las dinámicas internas de los procesos de trabajo que fomenten el desarrollo de las prácticas colectivas.

\section{DESCRIPTORES}

Consumidores de drogas

Atención Primaria de la Salud

Estrategia de Salud Familiar

Personal de salud 


\section{INTRODUCTION}

This work is based on the assumption that practices oriented toward drug users in primary health care (PHC), like most practices that integrate the work processes in the health care production process, consider the addiction/addict aspect as the element to be taken care of. This happens because the harmful consumption of drugs was historically considered to be a mental illness under Brazilian public health policy ${ }^{(1)}$. It is also assumed that the most recent changes in PHC and in ministerial guidelines related to actions in regard drug use problems are not capable of changing this historic trend.

The history of care for drug users in PHC is marked by the fragmentary constitution of Brazilian public health policies, particularly of policies and practices addressing the harmful consumption of drugs. The care model for this group has always been linked to the multifactorial model of health and disease ${ }^{(2)}$, with so-called primary prevention assigned to schools in an authoritative way ${ }^{(3)}$ and treatment assigned to psychiatry, once the use of drugs has been generally defined as a disease ${ }^{(2)}$.

By proposing the building of a care network for drug users that is community-based, governed by the principles of the unified health system (SUS) and by the transversalization of logic, the current policy of the Ministry of Health has required a review of existing PHC care models. The Ministry of Health policy acknowledges the importance and centrality of PHC in the building of a care network for drug users, and the literature acknowledges PHC as an important locus for action in the field ${ }^{(4-5)}$.

The restructuring of PHC by Family Health Strategy (FHS) gave priority to a set of health problems in a group of people grossly defined as SUS-dependent, and in the government documents, as at risk/vulnerable groups for these health problems. The objective was to extend the care coverage. The changes made through operational norms left a sizeable set of health needs outside the scope of primary care(6).

Therefore, there is no history of accumulation of care for drug users in PHC so far, which is sidelining health professionals in the debate about care for this group. The analysis of the literature enables us to see the deficiency and/or absence of practices oriented toward drug users in $\mathrm{PHC}^{(4-5,7-8)}$. This level of care is historically disregarded in care for drug users, who are defined as ill/dependents; when they request the services of PHC they are usually sent to specialized services such as Psychosocial Care Centers for Drugs and Alcohol (CAPS-AD) or hospitalization.

The training of health professionals on the drug use issue has proved to be lacking and incapable of breaking with the biomedical model of health/disease or the commodification of health and the ideological foundations of public policy. Consequently, professionals are unable to break with the biomedical concept of drug use ${ }^{(4-5,9)}$.
The objective of this study was to analyze practices oriented toward drug users in PHC services, taking as a reference Brazilian public health policies in this field.

\section{METHOD}

This research is based on a Marxist approach to knowledge production, which strongly contributes to collective health in Latin America and integrates the critical paradigm $^{(10)}$. In particular, the current study leans on the development of the theoretical-methodological approach that explains the problems with drug users considering their commodification $^{(2,11-12)}$.

From this point of view, practices in PHC are considered to be instruments of the work processes in the health care production process to meet the needs in this field ${ }^{(13)}$. These needs are understood as a need for social development, and to consider them as the object of health practices, requires a broad understanding of all aspects, particularly economic, given its importance in capitalism ${ }^{(14)}$.

The research presents a qualitative study of a descriptiveanalytical nature, carried out in 2012, using as the field of study a basic health care unit (UBS) located in the municipality of São Paulo, where both the FHS and traditional care models are found.

The UBS has six family health professionals, who serve approximately $90 \%$ of the people covered by the unit. Some specialized doctors treat patients who are outside the coverage area of the FHS, but the psychiatrist and the pediatrician also treat FHS patients. The UBS also has a family health support center (NASF) composed of professionals who work for four health care units that are part of the Technical Supervision in Health (STS) of the Ipiranga borough, totaling 15 FHS teams.

The APDM, an association for the development of medicine from São Paulo, through a management contract with City Hall, took on the management of this UBS in 2001 with the implementation of the first FHS teams and was responsible for recruiting all staff members for this strategy and the NASF.

The research subjects were: six workers from FHS; three workers from City Hall and one worker from NASF. The inclusion criterion was to have experience in meeting demands related to the use of drugs, which was communicated at the end of the research project presentation meetings.

Data were collected from recorded interviews carried out with the help of a semi-structured script, upon the consent of the interviewees and the signature of a Free and Informed Consent Form. The project was approved by two Research Ethics Committees (of the School of Nursing of the University of São Paulo and São Paulo City Hall), and it was formally presented to the Center for Continuing Education of the Regional Coordination of Health of the southeastern region, which guided the operational execution. 
The data analysis followed the basic guidelines for analysis of content ${ }^{(15)}$, which were reviewed based on theoretical categories that helped to analyze the structural and dynamic aspects of the reality found. The subjects who brought the content were taken into consideration in a critical manner, as well as their way of interpreting reality and the context in which this content is presented ${ }^{(10)}$.

\section{RESULTS}

The analysis of the results allowed for the identification of three major topics among the content brought up by the interviewees:

\section{Absence of demands related to the use of drugs in PHC.}

In this topic, the components were identified. The first concerns aspects that make the use of drugs difficult to understand: a) Concepts that help professionals to identify the object of the care-giving leads them to see drug users as incapable, weak, vulnerable, helpless, ill, or deviant; b) Aspects of the training of professionals that prevent them from meeting demands related to the use of drugs are absence or lack of training on the topic; the hegemony of clinical/biomedical training, based on the psychiatric model; absence of instruments to promote change in the object of work (a cause for distress, as there are no effective answers, which results in the mobilization of professionals to seek training on their own); failure in the implementation of significant changes in specific courses (the low impact of actions is attributed to the absence of a practical instrument that teaches how to approach drug users). The second concerns demands related to the use of drugs that come to PHC and are not reinterpreted as health needs: demands are taken and met (or not) in the way they are brought and expressed by users and relatives, without any reinterpretation (if it is brought as hospitalization, it is considered as hospitalization); difficulties in having these demands reach PHC, as there is no kind of active search, despite being an acknowledged as a serious matter in the territory; the demands that do make it to the service come in as severe cases, brought by relatives or by community health agents; the individuals search for help primarily because of relatives' despair, and sometimes the users themselves, when they cannot deal with the problem; there are statements that also indicate that demands related to the use of drugs do not come directly, that is, the drug users come to the service with other demands/complaints and, despite the fact that demands are resignified by health professionals, the acknowledgment of the needs that lie behind these demands is not achieved; the forms of organization of work processes in PHC do not contribute to the identification and acknowledgement of the needs of people treated in PHC; there is no adequate intervention in needs among the practices, so the only resource is to support/reduce the need for this model of care; the most frequent demand in UBS is for hospitalization.
Protocol formalities are insufficient: a) insufficient means and instruments to deal with complex matters that are intertwined with the use of drugs; the main practices oriented toward drug users are limited to private consultations, home visits and referral to other care services or specialized professionals; the object of work processes are cases that can reach the services; these practices strictly follow what is suggested by manuals and flow charts, that is why we call them 'protocol formalities'; b) even practices of specialized professionals do not expand the object of work processes, which is still the incapable, weak and ill individual; professionals do not have enough resources to expand the object and convert the demands that are brought by drug users and families into health needs; there are difficulties in creating practices that expand the object of work processes, as these processes are subject to regulation by protocols and programs established by health policies, at a central level and without the participation of workers and people living in the places served; the main instrument of the work process becomes maintenance of a link, when the object is the drug users and their demands.

Inefficiency of the biomedical and private model: The care network oriented toward the drug user is badly constructed; there is no integration between the mental health and PHC services, as well as inefficiency in the mental health model in the municipality; there is lack of knowledge regarding the reality of mental health for people living in that place; there is a contradiction between this reality and the interventions made by health services in the municipality; the lack of integration of the health network service goes against the main principle of SUS, which is completeness of actions; the functioning of the mental health services network is known through manuals and flow charts.

\section{DISCUSSION}

The results indicate the existence of barriers in the care of drug users in PHC. Barriers are defined as those made by the historical absence of health care practices in PHC oriented toward drug users and by moralist ideologies. Demands related to the harmful consumption of drugs brought to PHC are usually not received and/or reinterpreted as health needs to trigger work processes. Despite the existence of mechanisms that make it difficult or even impossible for demands related to the use of drugs to reach PHC, some can overcome the barriers, but they are still not reinterpreted and come as they are. In that sense, this causes anguish and discomfort, and the workers are convinced that they are not technically prepared to address the problem with the users and their relatives.

This lack of preparation is not due to the insufficiency of the biomedical model in the interpretation of needs related to the use of drugs, but rather to the lack of technical training to deal with the demands, which turns out 
to be the main explanation for justifying the absence of practices oriented toward drug users in PHC. It is possible to observe that clinical/biomedical training based on the psychiatric model is chosen when it comes to dealing with drug use issues, with collective and mental health, which are relatively unknown models, playing a secondary role.

As a mechanism to relieve anguish and as a result of the absence of training spaces for health services development, especially in fields that are not included in the priorities of PHC, some professionals look for alternatives to technical training on their own. This search is driven by a personal commitment to meet these demands.

The care given to drug users in PHC is also studied by another author ${ }^{(9)}$, who observes that professionals focus on the importance of clinical training, which is almost always restricted to protocols of pharmacological intervention.

Historically, health services for drug users are restricted, in regard to not only quantitative aspects but also the types of approaches and interventions ${ }^{(16)}$. They reproduce the psychiatric and biomedical model that currently prevails and are characterized by excessive pathologization and medicalization of social problems ${ }^{(17)}$.

The subjects of the current study believe that a relationship becomes the main work instrument when the object is the demand brought by drug users. The appreciation of the human aspect would result in some comfort for the individuals who are suffering from the use of drugs, but this breath of fresh air does not seem to last and the same anguish returns as a result of the impossibility of reinterpreting the initial demands brought by users, families and neighbors.

The analysis of the perception that the individuals have concerning care for drug users in $\mathrm{PHC}$ refers to a cycle that promotes strengthening of the mechanisms that put PHC in a secondary position in which they are unable to provide interventions in health that could change the picture regarding the use of drugs.

When these professionals choose the demands of drug users as the object of a work process, they start from the concepts acquired during their training, their background, and ultimately, their own experience with psychoactive drugs. Generally speaking, this process reproduces the prevailing ideology. We did not observe questions raised or critical analyses regarding common sense and biomedical approaches, and the stereotypes about drug users were reproduced, those that state they are incapable, weak, helpless, ill, outlaws and deviants. The reproduction of this ideology, which supports the functionalist approach to the use of drugs $s^{(2,11,18)}$, underlies the justifications of health professionals in PHC concerning the difficulty of responding to demands related to the use of drugs and the absence and/or precariousness of care practices.
In setting out the drug use issue, health professionals include in their analysis the guilt of the individuals and their families, especially families considered to be dysfunctional. All the responsibility regarding the use of drugs falls upon the users, upon the treatment and eventually the successes or failures experienced in their lives. Other relevant aspects, such as the integration of these individuals in production and consumption processes and the social values that support these relationships ${ }^{(2)}$, were not given much importance.

Blaming the drug user is a process found in PHC and other spaces ${ }^{(19)}$, and it is related to more general guidance in the promotion of health, which is much criticized in the literature ${ }^{(2)}$.

The problematization made by the interviewees about the inconsistency among the demands, the health care services and the current care model is weak, with few arguments to justify it. The deterioration of work conditions, the recruitment process, the lack of a career plan, wages and job insecurity are left out of the equation. Current changes that are happening in the labor market are not evidenced, and they affect the field of health care and are related to productive restructuring and the growth of neoliberalism ${ }^{(6,20-22)}$.

Working conditions in PHC in São Paulo, which are directly influenced by changes that occur as a result of the neoliberal wave and are made real through social organizations (SO), create a working environment that favors worker alienation, as well as feelings of helplessness, stress, fear and insecurity ${ }^{(23)}$. These feelings are found among FHS nurses, for instance, and represent the main reason for exhaustion at work ${ }^{(24)}$.

All these feelings were put forward by the subjects of this research, who generally did not make any structural or dynamic analysis of their working conditions and pointed out the absence of this debate, as well as absence of favorable spaces and conditions for reflections about the forms of organization and management of the work processes and services in $\mathrm{PHC}^{(23)}$.

The fear of trafficking, violence and drugs is also pointed out by some professionals interviewed as a factor in limitation of care for drug users and in access to these demands in the UBS; this fear occurs in the context of the real drug trade that takes place in the region where they work. These conditions have been reported in other work spaces ${ }^{(19,25)}$.

This is due to distortions caused by the war against drugs, which disseminates a set of reactionary and counterproductive concepts regarding drugs and users. It advocates that social actions must be aimed at the fight against drugs and puts health and education professionals, as well as other social workers, in daunting circumstances such as those related to the production, circulation and use of illegal drugs. Based on research results, it has long been said that the problems related to drugs are of a social nature 
and they must be the focus of social workers. This means that working in this field involves actions on health determinants, actions that strengthen individuals and social groups in the search for social insertion and equality ${ }^{(2,11-12)}$

Occasionally, we see critical speeches that analyze the use of drugs from a commodification point of view, in which more general social dynamics are considered in the equation. In that sense, the object expands, but to maintain this in practice, it is necessary to improve knowledge and ensure the implementation of practices that take into consideration life and working conditions of different social groups that live within the coverage area of the UBS and which are the basis of health problems ${ }^{(1)}$.

Work in PHC continues to be done in a fragmented, compartmentalized and isolated way. Even with the restructuring proposal at this level and the implementation of FHS, there is no break with the prevailing biomedical care model and hegemonic forms of health intervention ${ }^{(23,26)}$.

In that sense, the modus operandi set out by the central bodies is imposed on the various front line workers, who must execute prescribed tasks and achieve expected results. There are few local planning spaces and some local assessment of actions, programs and projects, which could be spaces of reflection on work processes. The central bodies carry out assessments in an isolated manner and take into consideration only quantitative data (targets achieved, number of practices performed). But not even this information is discussed with health professionals, who are very pressured and have to comply with technical, shallow work ${ }^{(27)}$.

The way the work processes are organized in PHC and the absence of spaces for reflection about these processes, as well as the organization of health services themselves, prevent workers from qualifying the demands related to the use of drugs that reach PHC as health needs.

Besides, as the professionals who work together in the UBS have different relationships and wages, there are consequently different visions of the reality in which they exist. Those who have worked for the unit for many years show that they well know the life of the local population and health services, which is not the case for many new professionals of FHS, who do not have much experience.

The demands related to the use of drugs sometimes reach $\mathrm{PHC}$ and are interpreted as health needs. But workers who are facing those health needs cannot find an adequate intervention within the range of available practices. The only resource is to reduce these needs to ones for which they can find answers within the available practices, adjusting them to a care model.

The main practices oriented toward drug users in $\mathrm{PHC}$, as pointed out by the interviewees, restrict care for drug users to private consultations, home visits and referral to other levels of care or other specialized professionals. The object of the work process is cases that can reach the services. Such practices strictly follow what is suggested by manuals and flow charts defined by public policies about the matter and are not defined according to the health needs of the population living in the area. That is why we define these practices as protocol formalities.

The interviewees mentioned the absence of spaces for reflection on their practices. Considering that health services are reflexive work, and the object of work is extremely complex, it is essential to have spaces where various health professionals involved in the implementation of actions can create practices together in order to achieve comprehensive, not comparmentalized, care ${ }^{(28)}$.

The absence of such spaces eventually affects the execution of tasks as mere juxtapositions, so the teamwork is not characterized by collective work that imposes the articulation and integration of various work processes, with their particularities, specific aims, knowledge and instruments ${ }^{(28)}$. The development of instruments capable of converting demands related to the use of drugs into health needs is also affected.

The persistence of the hegemonic biomedical paradigm, even after the implementation of SUS, has created an abnormal health system, as the operational norms of SUS contradict its guidelines and principles. The political, legal and institutional framework that is the foundation of SUS proposes a comprehensive care model that is capable of ensuring the population a substantial access to health services, in a complete, equal and effective way, counting on a hierarchical service network that runs into a technical-operational aspect that is still based on the biomedical model (which has to do with the forms of organization of work processes and forms of health services) ${ }^{(29)}$.

The biomedical care model determines the formation of the whole care network, which is set out in a fragmented manner, as pointed out by the interviewees. It is incapable of articulating the various health services in order to give proper care to drug users and of changing the objects of the work process, which are still restricted to the disease ${ }^{(7-9)}$.

The process of health care services is supported and directly influenced by political, legal and ideological frameworks, which are created by the State and determine the organization of society. The current forms of health services in PHC and the organization of work processes of the different categories of professionals are influenced by hegemonic concepts and ideologies of a neoliberal nature. Such concepts go in the opposite direction from the principles of SUS and prioritize disintegrated and fragmented care, without a consistent network (only a series of services that are not related to each other), with actions focused on specific social groups ${ }^{(10)}$. 


\section{CONCLUSION}

The findings of this study allow us to conclude that PHC: reiterates reductionist social concepts about the use of drugs and users; mistakenly conceives that the object of care is out of its scope, as the drug addict is supposed to be cared for in specialized spaces; when the problem is present, it is seen as something abnormal for that space; some measures are taken in a precarious manner; as a result of the way work is set out in the health field, that is, strongly influenced by the capitalist logic of productivity, there are not many possibilities for the professional to reflect upon the matter; compartmentalized and mechanical work prevails; the instruments available in PHC do not help to resignify the demands that reach the service; practices related to the use of drugs are established based on spontaneous demands and norms and flow charts developed at central levels, without access to front line professionals; the training of health professionals is essentially technical-clinical, which does not help to break with ideological barriers of prohibition, the biomedical care model and the commodification of health; PHC professionals are not adequately trained to deal with complex issues such as the use of drugs; when a demand eventually overcomes the ideological barriers of stereotypes and prejudice and reaches $\mathrm{PHC}$, it has to face protocol formalities; the ideological tendency that tend to blame the user prevail, and the means and instruments available to professionals are inadequate for them to change the object of work in a broad manner so they can understand the health needs; the practices carried out from a simplified object with few possibilities of change tend to be too

\section{REFERENCES}

1. Santos VE, Soares CB, Campos CMS. Redução de danos: análise das concepções que orientam as práticas no Brasil. Physis Rev Saúde Coletiva. 2010;20(3):995-1015.

2. Soares CB. Consumo contemporâneo de drogas e juventude: a construção do objeto na perspectiva da Saúde Coletiva [tese livre docência]. São Paulo: Escola de Enfermagem, Universidade de São Paulo; 2007.

3. Soares CB, Jacobi PR. Adolescentes, drogas e AIDS: avaliação de um programa de prevenção escolar. Cad Pesqui. 2000;(109):213-37.

4. Gonçalves SSPM, Tavares CMM. Atuação do enfermeiro na atenção ao usuário de álcool e outras drogas nos serviços extrahospitalares. Esc Anna Nery Rev Enferm. 2007;11(4):586-92.

5. Barros MA, Pillon SC. Atitudes dos profissionais do PSF diante do uso e abuso de drogas. Esc Anna Nery Rev Enferm. 2007;11(4):655-62. simple and do not favor significant changes that would positively impact the way subjects relate to drugs; the absence of spaces for critical reflection and training is at the core of poor problematization of work processes, health care services and use of drugs. It is therefore difficult to overcome hegemonic concepts that come from hegemonic paradigms and the way contemporary social formation is organized; the situation presented shows that it is very difficult to create practices that are in line with the health needs of drug users.

We conclude that PHC has enormous potential to restructure health care for drug users, once it is a health service that is closer to the reality of various social groups living in an area where the process and outcomes of drug use actually take place. It is therefore essential that $\mathrm{PHC}$ play a role as part of the intersectoral work that must guide actions in the field. The State must recognize this potential and invest in the key role played by PHC in the setting out of SUS and as an essential locus for the implementation of care given to users of alcohol and other drugs.

The conclusions of this study allow us to propose the promotion of critical reflection about the work processes, in both training spaces and work spaces, in order to build a care network for drug users organized at the PHC level. This instrumentation must support the participation of professionals and drug users and their families within decision-making spaces, where public policies are defined and guide the actions of the State in the face of the use of drugs, as well as within management levels, where processes of health services are defined.

6. Calipo SM, Soares CB. Público e privado na reforma do Sistema de Saúde no Brasil. Soc Debate. 2008;14(1):119-38.

7. Vecchia MD, Martins STF. Desinstitucionalização dos cuidados a pessoas com transtornos mentais na atenção básica: aportes para a implementação de ações. Interface Comun Saúde Educ. 2009;13(28):151-64.

8. Munari DB, Melo TS, Oliveira MB, Barbosa CC, Queiroz ACCM, Araújo BFM. Capacitação de agentes comunitários de saúde para o cuidado em saúde mental na atenção básica: potencializando pessoas para cuidar de pessoas. Rev Tempus Actas Saúde Colet. 2010;4(1):115-23.

9. Moretti-Pires RO, Corradi-Webster CM, Furtado EF. Consumo de álcool e atenção primária no interior da Amazônia: sobre a formação de médicos e enfermeiros para assistência integral. Rev Bras Educ Med. 2011;35(2):219-28. 
10. Soares CB, Campos CMS, Yonekura T. Marxism as a theoretical and methodological framework in collective health: implications for systematic review and synthesis of evidence. Rev Esc Enferm USP [Internet]. 2013 [cited 2014 Mar 19];47(6):1403-9. Available from: http://www.scielo.br/pdf/ reeusp/v47n6/en_0080-6234-reeusp-47-6-01403.pdf

11. Soares CB, Campos CMS. Consumo de drogas. In: Borges $A L V$, Fujimore $E$, organizadoras. Enfermagem e a saúde do adolescente na atenção básica. Barueri: Manole; 2009.

12. Santos VE, Soares CB. O consumo de substâncias psicoativas na perspectiva da saúde coletiva: uma reflexão sobre valores sociais e fetichismo. Saúde Transf Social. 2013;4(2):38-54.

13. Mendes Gonçalves RB. Práticas de saúde: processos de trabalho e necessidades. São Paulo: Centro de Formação dos Trabalhadores em Saúde, Secretaria Municipal da Saúde; 1992. (Cadernos CEFOR, 1 - Série textos).

14. Campos CMS, Mishima SM. Necessidades de saúde pela voz da sociedade civil e do Estado. Cad Saúde Pública. 2005;21(4):1260-8.

15. Bardin L. Análise de conteúdo. Lisboa: Edições 70; 1977.

16. Soares BM, Rohden F. As melhores intenções: análise dos programas de prevenção e recuperação da dependência química. Rio de Janeiro: Núcleo de Pesquisa/ISER; 1994.

17. Alves VS. Modelos de atenção à saúde de usuários de álcool e outras drogas: discursos políticos, saberes e práticas. Cad Saúde Pública. 2009;25(11):2309-19.

18. Velho G. O estudo do comportamento desviante: a contribuição da antropologia social. In: Velho G, organizador. Desvio e divergência: uma crítica da patologia social. Rio de Janeiro: Zahar; 1974. p.11-28.

19. Soares CB, Campos CMS, Leite AS, Souza CLL. Young people and drug consumption: workshops to provide tools for workers in social institutions, from a collective health perspective. Interface Comum Saúde Educ. 2009;13(28):189-99.

20. Antunes R. A era da informatização e a época da informalização: riqueza e miséria do trabalho no Brasil. São Paulo: Boitempo; 2006. Riqueza e miséria do trabalho no Brasil; p.15-25.
21. Santos VC. A relação trabalho-saúde dos enfermeiros do PSF da região de Vila Prudente-Sapopemba: um estudo de caso [dissertação]. São Paulo: Escola de Enfermagem, Universidade de São Paulo; 2007.

22. Shimizu HE, Carvalho Junior DA. O processo de trabalho na Estratégia Saúde da Família e suas repercussões no processo saúde-doença. Ciênc Saúde Coletiva. 2012;17(9):2405-14.

23. Ribeiro EM, Pires $D$, Blank VLG. A teorização sobre processo de trabalho em saúde como instrumental para análise do trabalho no Programa Saúde da Família. Cad Saúde Pública. 2004;20(2):438-46.

24. Santos VC, Soares CB, Campos CMS. A relação trabalhosaúde de enfermeiros do PSF no município de São Paulo. Rev Esc Enferm USP. 2007;41(n.esp):777-81.

25. Cordeiro L. Formação de Agentes Comunitários de Saúde para o desenvolvimento de práticas de Atenção Básica relativas ao consumo prejudicial de drogas [dissertação]. São Paulo: Escola de Enfermagem, Universidade de São Paulo; 2013.

26. Favoreto CAO, Camargo Junior KR. Alguns desafios conceituais e técnico-operacionais para o desenvolvimento do Programa de Saúde da Família como uma proposta transformadora do modelo assistencial. Physis Rev Saúde Coletiva. 2002; 12(1):59-75.

27. Schraiber LB, Mendes-Gonçalves RB. Necessidades de saúde e Atenção Primária. In: Schraiber LB, Nemes MIB, MendesGonçalves RB, organizadores. Saúde do adulto: programas e ações na Unidade Básica. São Paulo: Hucitec; 1996.

28. Peduzzi M. Mudanças tecnológicas e seu impacto no processo de trabalho em saúde. Trabalho Educ Saúde. 2002;1(1):75-91.

29. Scherer MDA, Marino SRA, Ramos FRS. Rupturas e resoluções no modelo de atenção à saúde: reflexões sobre a estratégia de saúde da família com base nas categorias kuhnianas. Interface Comum Saúde Educ.2005;9(16):53-66. 